\begin{abstract}
This paper looks at the monetary policy decisions of the U.S. Federal Reserve and asks whether those decisions have been influenced solely by national concerns, or whether regional factors have played a role. All of the Federal Reserve's policymakers have some regional identity, i.e., either their positions explicitly carry some regional affiliation or their region of origin is a factor that must be considered in the selection process.

This research is relevant for the Fed, and it may also be relevant for Europe's fledgling central bank in Frankfurt. Critics have asserted that ECB policymakers have an incentive to base policy on national developments and respond to national political pressures.

We find that Fed policymakers do take into account developments in regional unemployment when deciding monetary policy, and that these regional developments are more important for central bankers at the hub than in the spokes. These findings are robust to a variety of different specifications of the voting equation.
\end{abstract}

Keywords: monetary policy, central banking

JEL classification codes: E58, F33

\title{
Acknowledgements
}

We would like to thank Jeffry Frieden, Charles Goodhart, Dale Henderson, David Howard, Peter Kenen, Richard Layard, David Stasavage, and seminar participants at the LSE for comments on an earlier draft, Norman Bernard and Cathy Tunis for invaluable documentation and references, Susan King and Justin May for research support at an early stage, and Sonia Muñoz for expert research assistance during the estimation phase of this project. All errors remain ours. The views in this paper are solely the responsibility of the authors and should not be interpreted as reflecting the views of the Board of Governors of the Federal Reserve System or of any other person associated with the Federal Reserve System. This paper is being issued simultaneously as International Finance Discussion Paper No. 721.

Ellen E. Meade is a member of the Centre for Economic Performance, London School of Economics. Contact: e.e.meade@1se.ac.uk. D. Nathan Sheets is on the staff of the Federal

Reserve Board, Washington, DC. Contact: nathan.sheets@frb.gov

This paper was produced as part of the Centre's International Financial Stability Programme

\author{
Published by \\ Centre for Economic Performance \\ London School of Economics and Political Science \\ Houghton Street \\ London WC2A 2AE
}

(C) Ellen E. Meade and D. Nathan Sheets, submitted February 2002

ISBN 0753019183

Individual copy price: $£ 5$ 


\title{
Regional Influences on U.S. Monetary Policy: Some Implications for Europe
}

\author{
Ellen E. Meade and D. Nathan Sheets
}

\section{February 2002}

$\begin{array}{llr}\text { 1. } & \text { Introduction } & 1 \\ \text { 2. } & \text { Literature Review } & 3 \\ \text { 3. } & \text { A Simple Framework } & 4 \\ \text { 4. } & \text { The U.S. Federal Reserve } & 6 \\ \text { 5. } & \text { Empirical Results } & 14 \\ 6 . & \text { Implications for Europe } & 19\end{array}$

Tables $\quad 22$

$\begin{array}{ll}\text { References } & 34\end{array}$ 


\title{
Regional Influences on U.S. Monetary Policy: Some Implications for Europe
}

\begin{abstract}
Convenience and efficiency in coin and currency distribution and in check-processing may be the least of the benefits flowing from this far-flung network of offices, stretching from Seattle to San Antonio and from Buffalo to Birmingham. Our System's broad geographic reach also ensures that we who have the privilege of serving as policymakers - the presidents of the regional Banks and the Board members in Washington - receive a clear sense of the economic and business life beyond the Beltway, which encircles the nation's capital. As keen observers of local economies, the directors here and elsewhere contribute vitally to the formulation of monetary policy by offering important insights absent, by definition, from even the most careful analysis of aggregate data. Often they know what is happening in the various regions of the country well before the hard data are collected by national statistical agencies. Most importantly, this singular system of broad and diverse representation, nurtured by close contacts at the regional and local levels, fosters a long-term perspective and a continuity.
\end{abstract}

Alan Greenspan, December 2000.

\section{Introduction}

The Federal Reserve System is a hybrid institution, designed to represent and respond to national and regional concerns at the same time. The Fed's responsibilities are numerous, ranging from the setting of monetary policy for the nation to the supervision of banks and the clearing of checks at the local level. This paper looks at monetary policy decisions and whether those decisions have been influenced solely by national concerns, or whether regional factors have played a role.

In particular, all of the Federal Reserve's policymakers have some regional identity, i.e., either their positions explicitly carry some regional affiliation or their region of origin is a factor that must be considered in the selection process. What we seek to determine is whether there is any systematic evidence that policymakers have cast their votes according to economic developments in their region rather than focusing exclusively on developments in the national economy. For instance, were policymakers from California more sensitive to that state's sluggish economic performance following the defence cutbacks and base closures in the early 1990s? 
This research is relevant for the Fed, and it may also be relevant for Europe's fledgling central bank in Frankfurt. Critics have asserted that ECB policymakers have an incentive to base policy on national developments and respond to national political pressures. Moreover, since national statistics for each country that has adopted the euro remain the major source of information, it is straightforward to assess economic developments from the national perspective (much easier, for example, than to judge local developments in the United States where fewer disaggregated indicators are published).

A generic central bank structure is useful in outlining this problem. The main office of the central bank sits in a single location, with additional regional offices throughout the currency area, forming the hub and spokes of the system. Central bankers in the main office and the regional offices participate in monetary policy decisions. All central bankers, whether in the hub or the spokes, by definition have some regional identity. The question we ask in the paper is: are policymakers in the main office, the regional offices, or both, influenced by regional information in making monetary policy decisions? That is, once areawide data are taken into account, do votes of policymakers appear to have been influenced by regional developments? It is possible to examine this hypothesis for the Federal Reserve owing to the available detail on meetings and voting records of its monetary policy committee. To preview our results, we find that Fed policymakers do take into account developments in regional unemployment when deciding monetary policy, and that these regional developments are more important for central bankers at the hub than in the spokes. Our findings are robust to a variety of different specifications of the voting equation.

This paper is organized as follows: the next section reviews the literature on monetary policy voting in the United States; Section 3 lays out a simple framework for analysing our question; Section 4 discusses in detail the Federal Reserve's policymaking structure, our sample of monetary policy votes, and correlations among those votes and regional unemployment; Section 5 details our empirical results; Section 6 examines the implications of these results for the ECB. 


\section{Literature Review}

The literature on Federal Reserve monetary policy voting can be grouped into two strands: first, articles that take inspiration from the partisan theory of politics, and second, articles that take inspiration from monetary policy reaction functions.

The partisan theory of politics is rooted in Hibbs (1977) and refined in Alesina (1987) and Alesina and Sachs (1988). This theory generally assumes that political factors are important determinants of behaviour; more specifically, Democrats and Republicans occupy different points on the trade-off between unemployment and inflation, with Democrats presumed to be less attentive to inflation and more attentive to unemployment than Republicans. Numerous prior studies of Federal Reserve voting - including articles by Belden (1989), Havrilesky and Schweitzer (1990), Havrilesky and Gildea (1991, 1992, 1995), and Gildea $(1990,1992)$ - have examined monetary policy votes cast by U.S. central bankers at the institutional hub, at the spokes, or both.

This first strand has generally focused on the background characteristics and political affiliations of central bankers and whether those characteristics or affiliations can be used to predict votes cast in monetary policy decisions. Empirical findings from this research are that central bankers from the regional offices are more likely to cast dissenting votes in monetary policy decisions; dissents are more likely to be for tighter than for easier monetary policy; central bankers appointed by Democrats tend to dissent less frequently for tightening than central bankers appointed by Republicans; an advanced degree in economics is associated with tightening dissents; and number of years in government service is associated with easing dissents.

This literature has been widely perceived as giving strong support for the hypothesis that central bankers from regional offices are more independent and more hawkish on monetary policy than central bankers from the main office. However, there is a major empirical flaw with this work in that the voting sample is truncated either by ignoring votes cast in agreement with the majority or by looking only at split-decision outcomes. The effects of this sample selection bias are potentially significant. For example, over the sample period examined in this study (1978-2000), split-decisions were recorded in about half of all meetings, while dissents were only 8 percent of total votes cast. 
Turning to the second strand, the literature on monetary policy reaction functions generally uses the realized, ex post interest rate as the central bank's target. ${ }^{1}$ However, using votes cast by Fed policymakers, Tootell (1991a, 1991b) takes a somewhat different approach, estimating an intended, ex ante monetary policy reaction function. In his framework, votes in agreement with the majority as well as dissents are classified as votes for tighter, unchanged, or easier policy and explained in terms of forecasts for real output growth and price inflation. Contrary to the findings in the partisan strand of the voting literature, Tootell finds no evidence of a systematic difference in the voting behaviour of policymakers from the central bank's main office or its regional offices. ${ }^{2}$

Two studies, Gildea (1992) and Tootell (1991a), have asked whether votes cast by policymakers from the Fed's spokes have been influenced by regional information. While Gildea finds some limited evidence that regional developments influence the votes of central bankers from regional offices, his results are suspect owing to sample truncation. Tootell finds no statistical support for the hypothesis, however, and his results are robust to a variety of different specifications and data definitions. Our work differs from Tootell's in three major respects: first, our dependent variable differentiates between votes cast with the majority or in dissent; second, the variables we use to measure regional developments are calibrated more precisely to the geographical definition of the regions; and third, we take into account the regional ties of policymakers in the Fed's main office as well as the ties of officials in the regional spokes in testing whether regional developments influence votes cast.

\section{A Simple Framework}

An intuitive theoretical framework motivates the empirical approach used in this study. If $i$ indexes voters on the monetary policy committee and $t$ indexes time, we can represent voter $i$ 's desired or "target" short-term interest rate $\mathrm{ST}_{i t}$ as

$$
\mathrm{ST}_{i t}=\mathrm{F}\left(\mathrm{R}_{i t}, \mathrm{~N}_{t}\right)
$$

\footnotetext{
${ }^{1}$ See, for example, Abrams, Froyen, and Waud (1980).

2 Tootell does not include social and political factors among his explanatory variables.
} 
where $\mathrm{R}_{i t}$ is a vector of variables describing developments at time $t$ in voter $i$ 's region of origin, and $\mathrm{N}_{t}$ is a vector of national variables at time $t .^{3}$ We term equation (1) an individual reaction function. A specific example of such a function might be the following linear relationship:

$$
\mathrm{ST}_{i t}=\mathrm{a}_{i} \mathrm{R}_{i t}+\beta_{i} \mathrm{~N}_{t}
$$

Equations (1) and (2) suggest that individual voters have different views regarding the appropriate short-term interest rate for three reasons: first, regional information $\left(\mathrm{R}_{i t}\right)$ may vary; second, responsiveness to regional information $\left(\mathrm{a}_{i}\right)$ may vary; third, responsiveness to national information $\left(\beta_{i}\right)$ may vary (for example, some committee members may want to respond more aggressively than others during periods when output is above trend).

It is not possible to estimate individual oter reaction functions as described in (2) because the $\mathrm{ST}_{i t}$ 's are not observable. For decisions of the Federal Reserve, variables that are observable include the decision of the majority of committee members ${ }^{4}$ and in the case of a dissent, whether the voter preferred a tighter or easier policy than the majority. Given equation (1), it follows that the decision of the majority of members, $\mathrm{ST}_{t}^{c}$, is a function of regional and national variables as described by the policy reaction function

$$
\mathrm{ST}_{t}^{c}=\mathrm{G}\left(\mathrm{R}_{1 t}, \ldots, \mathrm{R}_{n}, \mathrm{~N}_{t}\right) \quad \text { where } i=1, \ldots, 12
$$

Equation (3) resembles a conventional monetary policy reaction function, where the majority decision is taken as the realized short-term interest rate. Studies that have estimated such policy reaction functions typically ignore any information provided by dissenting votes. ${ }^{5}$

We now define functions $\mathrm{h}_{i t}\left(\mathrm{Z}_{i t}\right)$ and $\mathrm{d}_{i t}\left(\mathrm{Z}_{i t}\right)$ as threshold deviations from the committee decision $\mathrm{ST}_{t}^{c}$ for voter $i$ at time $t$, where $\mathrm{h}_{i t}\left(\right.$ ?) $>0$ and $\mathrm{d}_{i t}($ ?) $<0$ for all $i, t$. Voter $i$ will dissent from the committee decision when his desired short-term interest rate is sufficiently above or below the rate chosen by the majority. When

$$
\mathrm{ST}_{i t}-\mathrm{ST}_{t}^{c}=\mathrm{h}_{i t}\left(\mathrm{Z}_{i t}\right)
$$

\footnotetext{
${ }^{3}$ The regional variables $\mathrm{R}_{i t}$ need not be unique to voter $i$ if another member of the monetary policy committee hails from the same region.

${ }^{4}$ Since July 1995, the Fed's monetary policy committee has made public its target for the short-term interest rate.

${ }^{5}$ An exception is Tootell (1991a, 1991b).
} 
then voter $i$ will favour a higher rate (i.e., a more hawkish policy) than the majority, and when

$$
\mathrm{ST}_{i t}-\mathrm{ST}_{t}^{c}=\mathrm{d}_{i t}\left(\mathrm{Z}_{i t}\right)
$$

then voter $i$ will favour a lower rate (i.e., a more dovish policy) than the majority.

In principle (as indicated by the subscripts), the $h($ ?) and $d(?)$ threshold functions may vary across time and across individual voters, and may be determined by characteristics such as whether the voter is from the main office or a regional office of the central bank, the ability of the committee chairman to forge cons ensus, or the political affiliation of the voter.

Following from equations (3), (4), and (5), we define a limited dependent variable $\mathrm{VL}_{i t}$ that takes values of $(+1,0,-1)$ as follows: ${ }^{6,7}$

$$
\begin{array}{ll}
\mathrm{ST}_{i t}-\mathrm{ST}_{t}^{c}=\mathrm{h}_{i t} & \mathrm{VL}_{i t}=+1, \\
\mathrm{~d}_{i t}<\mathrm{ST}_{i t}-\mathrm{ST}_{t}^{c}<\mathrm{h}_{i t} & \mathrm{VL}_{i t}=0, \\
\mathrm{ST}_{i t}-\mathrm{ST}_{t}^{c}=\mathrm{d}_{i t} & \mathrm{VL}_{i t}=-1 .
\end{array}
$$

\section{The U.S. Federal Reserve}

\section{Structure and size}

The Federal Reserve System is composed of a central hub - the Board in Washington - and twelve regional spokes or "Banks" that are located throughout the country. The seven central bankers at the hub are "Board members," while the twelve in the regional spokes are "Bank presidents." 8

\footnotetext{
${ }^{6}$ In this framework, the dependent variable will not capture the relative movements of the short-term interest rate target over time, since the majority vote is mapped into the value of 0 for every $t$. Since our objective is to understand what factors explain dissenting votes, this characteristic of our framework is not a concern.

${ }^{7}$ Tootell $(1991 \mathrm{a}, 1991 \mathrm{~b})$ employs a limited dependent variable $\mathrm{VL}_{4}(+1,0,-1)$ defined as follows:

$\begin{array}{ll}\mathrm{VL}_{i t}=+1 & \text { if } \mathrm{ST}_{i t}-\mathrm{ST}_{t}^{c}=\mathrm{h}_{i t} \text { or if } \mathrm{d}_{i t}<\mathrm{ST}_{i t}-\mathrm{ST}_{t}^{c}<\mathrm{h}_{i t} \text { and } \mathrm{ST}_{t}^{c}-\mathrm{ST}_{t-1}{ }^{c}>0, \\ \mathrm{VL}_{i t}=0 & \text { if } \mathrm{d}_{i t}<\mathrm{ST}_{i t}-\mathrm{ST}_{t}^{c}<\mathrm{h}_{i t} \text { and } \mathrm{ST}_{t}^{c}-\mathrm{ST}_{t-1}=0, \\ \mathrm{VL}_{i t}=-1 & \text { if } \mathrm{ST}_{i t}-\mathrm{ST}_{t}^{c}=\mathrm{d}_{i t} \text { or if } \mathrm{d}_{i t}<\mathrm{ST}_{i t}-\mathrm{ST}_{t}^{c}<\mathrm{h}_{i t} \text { and } \mathrm{ST}_{t}^{c}-\mathrm{ST}_{t-1}{ }^{c}<0 .\end{array}$

Tootell's dependent variable tracks relative changes in the Fed's interest rate target over time. Dissents in favor of tighter (easier) policy are classified identically to majority decisions for tightening (easing).

${ }^{8}$ For details on the structure of the Federal Reserve System, see Purposes and Functions (1994).
} 
The twelve regions are not equal in size. Many U.S. states are apportioned to two or more of the regional spokes and one state, Missouri, is home to two Federal Reserve Banks. The geographical configuration of the system dates to 1914. Garnering political support for passage of the original Federal Reserve Act and balancing the interests of the numerous banks in the heartland against the interests of the New York financial community were key to the design of the system. ${ }^{9}$

The size of the twelve Federal Reserve regions can be measured in a number of ways. Table 1 looks at size in terms of nominal assets of the regional Federal Reserve Banks, population, real output, geographical area, and votes cast. In terms of assets on the balance sheets of the individual Federal Reserve Banks, a rough measure of the financial size of each region, New York ranked as the largest region in 1990 with more than one-third of total assets, followed by Chicago and San Francisco (which accounted for 13 percent and 10 percent of the total, respectively). ${ }^{10}$ By the asset measure, five of the twelve Federal Reserve banks - Dallas, Kansas City, Minneapolis, Philadelphia, and St. Louis - were quite small, each accounting for less than 5 percent. ${ }^{11}$

Population figures give a somewhat different perspective on the size of Federal Reserve regions. Nearly 20 percent of U.S. residents live in the San Francisco region. Atlanta and Chicago each lay claim to about 13 percent of the population, while New York ranks fourth with just under 10 percent. Using GDP to evaluate region size produces a similar ranking. The San Francisco region is largest (21 percent), followed by New York, Chicago, and Atlanta (each with about 11 percent). ${ }^{12,13}$

The final column of Table 1 gives another metric of region size: the average number of votes cast by representatives of each region at meetings of the Fed's monetary policy

\footnotetext{
${ }^{9}$ Johnson (1995) provides a good summary of the founding of the Federal Reserve.

${ }^{10}$ See Annual Report of the Board of Governors of the Federal Reserve System, 1990.

11 It is interesting to compare the 1990 distribution of Reserve Bank assets with what existed shortly after the founding of the system in 1920. While New York was by far the largest region with nearly one-third of total assets, Chicago and Cleveland were next in line with 15 percent and 10 percent, respectively. The San Francisco bank ranked sixth. The change in distribution from 1920 to the present day is consistent with the increase in economic activity in the western part of the United States over that period.

${ }^{12}$ For U.S. states that fall into more than one Federal Reserve region, population shares were used to allocate state output across regions. (Population can be estimated precisely by aggregating across all counties in a Federal Reserve regions, as counties are not split.) Fourteen U.S. states are assigned to more than one Federal Reserve region.

${ }^{13}$ The land area of each district in square miles gives yet another picture of size. By this measure, San Francisco is far and away the largest, followed by three other mid-western regions - Dallas, Minneapolis, and Kansas City.
} 
committee, the FOMC. ${ }^{14}$ The FOMC comprises the seven Board members, the President of the Federal Reserve Bank of New York, and four of the other eleven Bank presidents who vote on a fixed rotation. ${ }^{15}$ Each of the seven Board members hails from a different region. The calculations on average votes cast take into account the regional affiliations of Board members as well as those of Bank presidents.

In our sample of 345 meetings ${ }^{16}$ between 1968 and 2000, the New York region cast nearly 2 votes on average at each meeting, outstripping the other regions by a sizable margin. Five of the regions cast about one vote per meeting (Boston, Dallas, Kansas City, Philadelphia, and San Francisco), while two had somewhat more influence (Chicago and Richmond) and four had considerably less influence (Atlanta, Cleveland, Minneapolis, and St. Louis).

Table 2 provides the statistics on size as a rank ordering from the largest to smallest Federal Reserve region (numbered 1 to 12, respectively). Somewhat surprisingly, the average number of votes cast by Federal Reserve regions in monetary policy decision bears little relationship to our measures of economic size. Some regions - for example, Chicago, Minneapolis, and St. Louis - have a voice in monetary policy that about accords with their size. Atlanta and Cleveland have generally had less of a voice in policy decisions than their size would suggest is appropriate, while Philadelphia has had substantially more. New York and San Francisco are arguably the largest; while New York has had the most influence on monetary policy, San Francisco ranks far below New York in terms of votes cast.

\section{Monetary Policy Votes}

The sample of FOMC voting records used in our empirical analysis consists of 214 meetings conducted face-to-face and via conference call from 1978-2000. ${ }^{17}$ Summary information

\footnotetext{
14 The FOMC was not established until the 1930s. The policymaking structure envisioned under the 1913 legislation that created the U.S. central bank was quite different from the FOMC particularly with respect to the distribution of power between the centralized hub and the twelve spokes. See Meade and Sheets (1999).

${ }^{15}$ A 1942 amendment to the Federal Reserve Act prescribed a rotation of four seats on the FOMC among eleven Federal Reserve districts (excluding New York). This annual rotation began on March 1, 1943; since 1990, the rotation has taken place each year on January 1. One voting seat is rotated in a fixed fashion among: Cleveland and Chicago; Atlanta, Dallas, and St. Louis; Boston, Philadelphia, and Richmond; Kansas City, Minneapolis, and San Francisco.

${ }_{16}$ The sample includes meetings conducted face-to-face and via conference call.

${ }^{17}$ The annual number of meetings, face-to-face and via conference call, varies over the sample. In 1978 (and in earlier years), face-to-face meetings numbered 12 per year. A formal change reduced the annual number to 8 in 1981. Conference calls at which votes were recorded have been rare since 1982. Between 1978 and 1982, such calls were important in the policy process and the frequency likely reflects the significant changes in Fed operating procedures and leadership during those years. (Conference calls at which votes were not recorded are excluded from our analysis.) Data frequency is shown in the table below:
} 
Interestingly enough, all of the 31 dissents cast by the Boston member of the Board were in favour of tighter monetary policy, while all of the 31 dissents cast by the Chicago member were in favour of easier monetary policy. ${ }^{21}$

\section{Importance of regional identity}

In other studies of FOMC voting, the regional identity of Board members has been ignored. Many of the studies presume implicitly that Board members retain no regional loyalty, but rather represent the federal bureaucracy in Washington and maintain an affiliation with the political party of the President who appointed them. By including the regional identities of Board members in our work, we are able to assess the assumption made in previous studies that the regional link is not significant. The importance of this regional tie is ultimately an empirical question.

The 1913 Federal Reserve Act requires that Board members come from different regions. This requirement reflected fears that regional interests - those of Main Street or Wall Street - could come to dominate monetary policy. Thus, at the time of the System's founding, diversity on the Board was intended to promote policies that were nationally oriented and not overly sensitive to sectoral developments.

More recently, in 1996, President Clinton reportedly wanted to nominate Felix Rohatyn, a New York investment banker, to a vacant seat on the Fed's Board. As there was already a Board member (Alan Greenspan) from the New York region, consideration was given to nominating Rohatyn to the Kansas City seat because he owned vacation property in Wyoming. Rohatyn's name was eventually dropped, owing in part to anticipated difficulties with Senate confirmation for the Fed position (see Woodward, 2000).

A similar residency test surfaced in the Senate hearings for Lawrence Lindsey in 1991, although it did not de-rail the confirmation. After Lindsey answered several questions from Senator Paul Sarbanes about his long-term affiliation with Harvard University, the following exchange was recorded (see Hearings, pp. 45-46; italics added for emphasis):

Senator Sarbanes. All right. Now, for what geographic region are you being appointed to the Board to represent?

Mr. Lindsey. I'm representing the Richmond Federal Reserve District.

\footnotetext{
${ }^{21}$ Over the 1978-2000 period, the Boston seat was occupied by Henry Wallich, John LaWare, and Roger Ferguson, while the Chicago seat was filled by Nancy Teeters, Martha Seger, and Susan Phillips.
} 
Senator Sarbanes. What's your connection with the Richmond Federal Reserve District?

Mr. Lindsey. I own a house in Virginia. It's the only house that my wife and I own. I pay income taxes there, personal property taxes there, vote there. We've actually spent half our married life there, in two stints.

Senator Sarbanes. How much of your life have you spent there?

Mr. Lindsey. Five years.

Senator Sarbanes. Out of how many?

Mr. Lindsey. Thirty-six.

Senator Sarbanes. Well. Half of your married life is not highly relevant to the nexus with the Richmond Reserve District, is it?

Mr. Lindsey. Well, Senator, my -

Senator Sarbanes. Why do you think that requirement is in the law, in the Federal Reserve law? Why was it put there? Why do we have a geographical requirement? ... Wasn't one intent at least to get people from different regions of the country who participated in the economic life of their region to sit on the Federal Reserve Board making nationwide monetary policy? ... I don't understand how you under any stretch of the imagination would meet that criteria for the Richmond Reserve District.

Finally, transcripts from FOMC meetings offer some interesting insights into the regional identities of Fed Board members. Martha Seger, a Board member from 1984 until 1991, frequently mentioned economic developments in her home region of Chicago (which includes Detroit, home of the U.S. auto industry) to buttress her views on the national economy: ${ }^{22}$

My basic reason for going this way is that I'm impressed by the slowing that I see in the economy. Certainly, at least in the Detroit area, [economic activity] is way above where it was two years ago and yet the rate of increase is definitely slowing. And I'm also impressed by the chances for an auto strike this fall. (Federal Open Market Committee Transcripts, July 1984, p. 41; Seger voted with the majority to hold monetary policy unchanged.)

\footnotetext{
${ }^{22}$ These are just two of multiple instances in which Seger makes reference to developments in her home region of Chicago.
} 
I have just a couple of comments, primarily based on some conversations I had with people in the auto industry... As I looked at the general statistics, I thought the consumer looked as if he or she was pretty tight-fisted.... People point to auto sales as some sort of exception, but at least the people I spoke with in the auto industry are not putting that kind of interpretation on this.... (Federal Open Market Committee Transcripts, March 1988, p. 49; Seger dissented for easier monetary policy.)

Although these examples do not provide definitive evidence that regional developments influence Board members, they at least suggest that regional considerations are sometimes a factor in voting patterns.

\section{Votes and regional unemployment}

Our statistical analysis suggests that FOMC voting patterns are not insensitive to labour market conditions in Federal Reserve regions. We constructed monthly unemployment rates for each Federal Reserve area by weighting state unemployment rates by population shares in each region. ${ }^{23}$ We examined the difference between the regional and national unemployment rate for each month of an FOMC vote. Table 4 provides a frequency distribution of this difference in unemployment rates sorted by vote (votes with the majority, dissents in favour of easier policy, and dissents in favour of tighter policy). The next three paragraphs discuss these striking results in some detail.

Over the 1978-2000 period, FOMC voters, on average, had regional unemployment rates that were a touch below ( 0.1 percentage point) the national average. This suggests that the balance of power on the FOMC was tilted slightly toward regions with relatively strong economic performance.

FOMC voters dissenting in favour of easier monetary policy had regional unemployment that was above the national rate by an average 0.5 percentage point. A t-test strongly rejects the null hypothesis that the mean difference in regional and national unemployment rates for these voters is equal to the mean difference for all votes cast. Notably, when the unemployment rate in a member's region was more than 1.5 percentage points below the national average, the member dissented for easier policy just 1.3 percent of

\footnotetext{
${ }^{23}$ Monthly unemployment data for all U.S. states except California begin in 1978; data for California are available from 1980. Population shares for each state in a Federal Reserve region were constructed at the county level using data from the 1990 Census. (The unemployment rate for the San Francisco region in 1978-79 was calculated by re-normalizing the population weights to exclude California for these two years.)
} 
the time. In contrast, when the unemployment rate in a member's region was more than 1.5 percentage points above the national average, the member dissented for monetary easing 9.9 percent of the time.

FOMC voters dissenting in favour of tighter policy had lower regional (relative to national) unemployment rates; the mean difference was minus 0.7 percentage point. A t-test strongly rejects the null hypothesis that the mean difference in unemployment rates for these voters is equal to the mean difference for all votes cast. The details of these results are roughly symmetric to those discussed in the previous paragraph. In those instances when the unemployment rate in a member's region was below the national average, the member dissented in favour of tightening 7.5 percent of the time but dissented in favour of easier policy only 1.6 percent of the time. Conversely, no member dissented in favour of tighter policy when his region's unemployment rate was more than 1.5 percentage points above the national average. However, when the unemployment rate in a member's region was more than 1.5 percentage points below the national average, he dissented in favour of tighter policy 9.8 percent of the time.

Table 5 provides the frequency distribution sorted by Board members and Bank presidents. The Board member results provide compelling evidence that dissenting votes are associated with large differentials between regional and national unemployment rates. On average, Board members dissent for easier monetary policy when the region's unemployment rate is 0.7 percentage point higher than the national unemployment rate, and dissent for tighter monetary policy when the region's unemployment rate is 1.1 percentage points lower than the national rate. The null hypothesis that the mean difference in unemployment rates for easing or tightening dissents is equal to the mean difference for all votes cast is strongly rejected.

The results for Bank presidents lend some limited support to the view that regional unemployment differentials influence voting behaviour. Over the sample period, Bank presidents dissented for tighter policy when the national unemployment was 0.4 percentage point above the region's rate. A t-test rejected the null hypothesis that this mean difference was equal to the mean difference for all votes cast by Bank presidents. In addition, Bank presidents dissented in favour of tighter policy with 9.9 percent probability when the unemployment rate in their region was below the national average, but only 5.2 percent of the time when the unemployment rate in their region was above the national average. Differentials in unemployment rates, however, do not seem to help explain the observed pattern of dissents by Bank presidents in favour of easier policy. 
Another important observation can be drawn from Table 5. Dissenting votes cast by Board members were split about evenly between dissents in favour of easing and dissents in favour of tightening. Bank presidents dissented for tighter policy six times more frequently than they dissented for easier policy.

\section{Empirical Results}

The sample of FOMC votes from 1978-2000 was used to define a limited dependent variable $\mathrm{VL}$ as in equation (6). Ordered logit was used to estimate the voting equation. We deemed this empirical technique more appropriate for addressing our problem than multinomial logit, commonly used in other studies of FOMC voting. Ordered logit takes advantage of the information provided by the implicit ordering of the dependent variable (where votes in the - 1 category reflect a preference for easier monetary policy than votes in the 0 category, and votes in the +1 category reflect a preference for tighter monetary policy than votes in the 0 category) to produce a single set of coefficient estimates and standard errors along with estimated threshold parameters or break points for each category.

Our initial specification of the ordered logit equation included a large set of independent variables, with characteristic, regional, and national variables as listed on Table 6. The regional and national variables were lagged one month relative to the date of the FOMC meeting. ${ }^{24}$

Characteristic binary variables were used to detect differences in voting behaviour between officials from the main office and the regional offices (BOARD), between face-toface meetings and conference calls (MTG), under different Federal Reserve chairmen during the sample period (MILLER and VOLCKER), ${ }^{25}$ and following the revelation that meetings were being tape-recorded (TAPE).

Regional economic developments were represented in the initial specification by the difference between the unemployment rate in the FOMC voter's region and the national rate (UNDIFF). In addition, we tested a regional "gravity" unemployment rate (GRVUND) for each region that was a distance-weighted average of the unemployment differentials for the

\footnotetext{
${ }^{24}$ For the most part, the time series variables are released with a one-month lag. Availability at the time of an FOMC meeting depends on when during a particular month a meeting occurred, but we deemed a one-month lag to be a reasonable approximation to the information set available to policymakers.

${ }^{25}$ No binary variable was included for Arthur Burns, who resigned as chairman at the end of January 1978.

Estimation of the regression begins in March 1978, owing to lags in the independent variables.
} 
eleven other regions. The gravity unemployment variable was intended to detect whether votes were sensitive to developments in regions that were close neighbours to the home region of the voter. Finally, we added two variables designed to pick up non-linear effects in extreme cases: TAILH, a dummy set equal to one for values of UNDIFF greater than or equal to 1.5; and TAILL, a dummy set equal to one for values of UNDIFF less than or equal to minus 1.5 .

National variables measured the change in and the level of real economic activity (growth in industrial production, IP; output gap, GAP; and unemployment rate, UN) and inflationary pressures (change in consumer prices, CPI) in the month prior to the FOMC vote. In addition, we experimented alternately in the initial specification with two measures of short-term interest rates: the Fed funds rate of the week prior to the FOMC vote (FEDFUND), and a variable that indicated whether monetary policy had been tightened, eased, or left unchanged at the previous FOMC vote (STANCE). These variables were included to test whether dissents are sensitive to the level of monetary stimulus in the economy or to recent changes in monetary stimulus.

\section{Coefficient estimates}

Initial estimation results are shown in Table 7. Our estimation strategy was as follows: from the two initial specifications, we eliminated explanatory variables based on statistical significance to arrive at the preferred equation, on which we focus our attention. Surprisingly few of the explanatory variables included initially survive in the preferred specification. In particular, no national variables appear to explain the decision to vote with the FOMC majority or against it. While national variables are critical in setting the overall stance of monetary policy, these variables do little to explain the tighter or easier policy preferred by dissenters. $^{26}$ The estimated coefficient on the regional variable UNDIFF is negative and highly statistically significant, indicating that a rise in the regional unemployment rate of the voter (for a given national rate) raises the likelihood of an easing dissent and reduces the likelihood of a tightening dissent (and conversely for a decline in regional unemployment). The significant, negative coefficient on the BOARD variable indicates that Board members are more likely than Bank presidents to dissent for easier policy and less likely than Bank

\footnotetext{
${ }^{26}$ It may be the case that national economic variables do explain the voting behavior for a particular individual or district bank. However, these variables are not important determinants across all Board members or voting Bank presidents.
} 
presidents to dissent for tighter policy. This result is consistent with the general finding in the FOMC voting literature that Bank presidents tend to be more hawkish than Board members. Meetings conducted face-to-face are associated with a significantly greater likelihood of a dissent for tighter policy than meetings held via conference call. Roughly one-half of all conference calls result in a tightening of monetary policy (only 20 percent for face-to-face meetings), resulting in a reduced likelihood of a tightening dissent for calls. ${ }^{27}$ During the Miller chairmanship, there was greater likelihood of a tightening dissent, presumably reflecting disagreement over the appropriate stance of policy during a period of very high inflation.

Table 8 displays estimation results for six alternative specifications of the preferred equation. We discuss each alternative specification before turning to the marginal effects.

In the first alternative specification, the chairman's votes are dropped from the sample. The Fed chairman plays a unique role in FOMC meetings, by making the policy proposal on which other members vote; by construction, therefore, the chairman never dissents. ${ }^{28}$ The coefficients and t-ratios estimated when the chairman's votes are excluded are nearly identical to the empirical results obtained using the entire voting sample.

The second and third alternative specifications split the sample into votes cast by Board members in the central bank's main office and votes cast by Bank presidents from the central bank's regional offices, respectively. The coefficient on the UNDIFF variable is much larger for Board members (alternative 2) than for Bank presidents (alternative 3), although both voting samples yield a significant, negative parameter estimate. These results suggest that it is officials in the central bank's main office, rather than those in its regional offices, who demonstrate greater sensitivity to regional developments.

In the United States, central bankers are concerned not with the unemployment rate per se, but with the deviation of unemployment from its natural rate. As constructed, the unemployment differential UNDIFF does not correct for the natural rate, and this may pose a problem particularly if a region's natural rate differs from the national one. To address this issue, we decomposed UNDIFF two components representing its longer-run average

\footnotetext{
${ }^{27}$ In many instances, if the economic horizon appears somewhat uncertain at a face-to-face meeting, policymakers will agree to defer a decision to a conference call when more economic information has become available.

${ }^{28}$ Blinder et al (2001) discuss the powerful role of the Fed's chairman as follows (p. 39): “The Fed's FOMC does vote in a formal sense, but it is widely known that individual members often do not vote their true preference. Instead, each committee memberdecides whether to support or oppose the chairman's policy recommendation, which is almost always made first. And Fed traditions dictate that a member should 'dissent' only if they find the majority's (that is, the chairman's) opinion unacceptable."
} 
(STRUC) and shorter-term deviation (CYC), as follows: STRUC was defined as the difference in 5-year centered moving average means of the regional unemployment rate and the national unemployment rate; ${ }^{29} \mathrm{CYC}$ was defined as the difference between the demeaned regional and national unemployment rates. In alternative specification four, the parameter estimate for STRUC is highly significant, negative, and relatively large in magnitude, while the CYC coefficient is insignificant. This result suggests that policymakers respond to longer-term movements in the unemployment differential. ${ }^{30}$

In the fifth alternative specification, we added dummy variables to detect the importance of regional identities for Board members and Bank presidents. ${ }^{31}$ While the estimated coefficient on UNDIFF remains negative and highly significant in this alternative, the magnitude of the parameter drops with the inclusion of the regional dummy variables. We discuss the estimated regional dummies further below.

In the sixth alternative specification, we combined the UNDIFF decomposition with the regional dummy variables. Once again, the inclusion of the regional dummies results in a decline in the magnitude of the regional variable (in this case, STRUC).

Our testing demonstrates that the importance of the unemployment differential is robust to a variety of specifications. The unemployment differential has a negative, statistically significant effect on votes cast by central bankers. Although the estimated impact of this differential diminishes if regional dummy variables are included in the estimation, the resilience of the result is striking.

In hopes of broadening the set of regional variables to include financial information, we constructed monthly data on bankruptcies by Federal Reserve region. We gathered monthly FDIC data on bankruptcies at the county level for number of failed institutions, value of assets at failed institutions, and value of deposits at failed institutions; from these county-level data, we constructed regional variables. We estimated many equations adding the bankruptcy measures in different ways, but this indicator never proved to be statistically important in explaining voting behaviour.

\footnotetext{
${ }^{29}$ Regional unemployment rates were constructed by interpolating annual data for the states prior to 1978.

${ }^{30}$ We also tested an equation in which CYC was included but STRUC was omitted. In that case, the coefficient on CYC was significant and negative.

${ }^{31}$ The omitted region was New York. In the case of Board members, there were not enough observations to estimate dummy variables for regions 4 and 9 (Cleveland and Minneapolis, respectively).
} 


\section{Marginal effects}

Table 9 displays marginal effects for the preferred specification and the six alternative specifications. The marginal effects give the change in the likelihood of each voting category for a small change in an explanatory variable. ${ }^{32}$

For the preferred equation, membership on the Fed's Board reduces the probability of dissenting for tighter monetary policy by 4.2 percentage points and increases the likelihood of agreement with the majority or dissenting for easier policy by 2.4 and 1.8 percentage points, respectively. At a face-to-face meeting of the FOMC, members are much more likely to register a tightening dissent and much less likely to register an easing dissent (2.3 and 1.9 percentage points, respectively) than during a conference call. Under Fed chairman Miller, policymakers were more likely to dissent for tighter policy and less likely to agree with the majority (by 3.7 and 2.6 percentage points, respectively). Finally, an increase in a region's unemployment rate relative to the national rate reduces the probability that a voter from that region will dissent for tightening by 2.3 percentage points. The calculated marginal effects of the explanatory variables are nearly identical for the first alternative equation, in which the votes of the chairman are dropped from the sample.

For alternatives two and three, it is interesting to compare the marginal effects for the UNDIFF variable. An increase in a region's unemployment rate (for a given national rate) reduces the probability that Board members and Bank presidents will dissent for tightening, but the reduction in probability for the former is larger (2.2 versus 1.5 percentage points, respectively). As a result, Board members are more likely to dissent for easier policy, while Bank presidents are more likely to agree with the majority. In alternative specification four, in which UNDIFF is replaced with its structural and cyclical components, the marginal effects for STRUC are very similar to those in the preferred equation.

With the inclusion of regional dummy variables in alternatives five and six, the marginal effects reveal that Board members and Bank presidents from certain regions are associated with large changes in the probabilities of dissent and agreement relative to the respective member from the New York region. For example, Board members from Boston,

\footnotetext{
${ }^{32}$ Chapter 19 of Greene (2000) provides a good discussion of ordered logit and the derivation of marginal effects. Marginal effects are computed by multiplying the estimated coefficient value by the probability density function evaluated over the relevant intervals (using the threshold parameters as interval break points), holding variables equal to their sample means. For binary variables, the computation is somewhat different: the predicted value of the dependent variable is computed for the dummy set equal to one and set equal to zero (with all other explanatory variables set equal to their sample means); the marginal effect is the difference between the former and the latter.
} 
and to a lesser extent Kansas City and Dallas, are relatively less likely to agree with the majority and more likely to dissent for tighter policy. Among Bank presidents, the regions of Cleveland and St. Louis are much more likely than the president from New York to dissent for tightening (shifting the probability by more than 20 percentage points) and correspondingly less likely to vote in agreement. This is also true for Bank presidents from Atlanta and Minneapolis, although to a lesser extent. With regional dummy variables in the equation, the shift in probabilities associated with the unemployment differential (UNDIFF and STRUC, respectively) diminishes considerably. A rise in the unemployment rate gap between a region and the nation (alternative five) reduces the probability of a tightening dissent by 0.8 percentage points.

\section{Implications for Europe}

The ECB's Governing Council, which formulates monetary policy for the euro area, is composed of officials from the hub and the spokes of the currency area. At present, the Council numbers 18: six policymakers from Frankfurt and twelve national central bank heads (the main office and the regional offices of the central bank, respectively, from the earlier paradigm). Unlike the Fed's system in which voting rotates among policymakers from the regional offices, each of the 18 members of the ECB's Governing Council casts a vote at every meeting. For euro-area countries with two representatives on the Governing Council (Finland, France, Germany, Italy, Netherlands, Spain), the share in total votes cast is 11.1 percent; for the remaining countries, the voting share is 5.6 percent.

As the European Union widens to include new countries to the east (perhaps as soon as 2004) and those countries join the euro area, the size of the Council will grow as new national central bank heads are added. ECB policymakers could rise to number more than twenty. As a result, policy discussions are likely to become increasingly unwieldy. Thus, the ECB may want to consider reforming the composition of its Governing Council so as to reduce its potential size. The agreement reached at the Nice Summit in December 2000 opens the door for such a reform, permitting an amendment that does not require a change in the Maastricht Treaty. ${ }^{33}$ While the structure of the Governing Council may not be changed, the Treaty of Nice permits a change in the voting rule; the current one-man-one-vote rule

\footnotetext{
${ }^{33}$ For an excellent overview of the Treaty of Nice and its implications for the ECB, see Baldwin, Berglöf, Giavazzi, and Widgrén (2001).
} 
could be replaced by a rule that requires the rotation of votes among groups of policymakers or the grouping of policymakers into voting blocs.

The enlargement of Europe's monetary union would not only increase the size of the Governing Council, it would also increase the relative number of policymakers from regional offices (heads of national central banks) relative to those from the main office in Frankfurt. Some have suggested that this shift in balance will make European monetary policy more subject to regional influence or the national biases of national central bank presidents (see Baldwin et al, pp. 77, 80-82). The results in this paper suggest that the regional biases of all policymakers ought to be considered, and that one should not rule out the possibility that central bankers in Frankfurt are as nationally biased as national central bank presidents.

To examine whether national loyalties may have played a role in ECB monetary policy to date, we performed an experiment that is inspired by our empirical results for the Fed's FOMC. We assumed that each member of the Governing Council casts his or her vote on the basis of the prior month's difference between national and euro-area inflation rates. (In light of the ECB's inflation objective and well-known problems with structural unemployment in European countries, we focused on inflation rather than unemployment in this exercise.) We further assumed that if the national inflation rate differs from the euro-area average by more than a threshold value in the month prior to the monetary policy meeting, the Governing Council member will vote in a particular fashion. For example, if national inflation is higher than euro-area inflation by more than the threshold value, then a policymaker from that country will vote in favour of monetary tightening or against monetary easing (and conversely if national inflation is below the euro-area average). We looked at each instance of a change in ECB policy since January 1999, and calculated the aggregate number of Governing Council members who would have voted contrary to the actual monetary policy change that was made, given our voting rule and a number of different threshold values.

These results of this exercise, which are reported in Table 10, are striking and indicate that ECB monetary policy decisions are not inconsistent with the regional bias hypothesis. Based on a simple majority voting rule, ${ }^{34}$ only in March 1999 with a threshold value of 0.25 do we find a majority of Governing Council members who would have voted against the actual policy change that was announced. That is, in nearly every case for every threshold value tested, the majority of ECB officials voted for a change in policy that can be justified in

\footnotetext{
${ }^{34}$ According to the ECB, no formal vote is taken at meetings of the Governing Council and that all decisions reflect consensus.
} 
terms of the differential between their national inflation rate and the euro-area average. Proposals for reform of the Governing Council's voting structure should consider in detail the ramifications of national biases on European monetary policy and potential voting structures that act to minimize these biases.

Baldwin et al favour a reform in which the six policymakers at the ECB's centre cast votes on monetary policy, while the policymakers from the regions (the national central bank presidents) attend the meetings and participate in discussions, but do not vote. Table 11 provides the results of our experiment for these six officials. Again, changes in euro-area monetary policy since January 1999 - had votes been cast only by the policymakers at the centre - have not been inconsistent with a voting rule based on inflation differentials. While Baldwin's proposed reform might streamline the ECB's decision-making process and prevent the number of voters from growing with the enlargement of monetary union, it might not prevent policymakers from exercising national loyalties. 
Table 1: Size of Federal Reserve Regions

\begin{tabular}{|c|c|c|c|c|c|c|c|c|c|}
\hline \multirow{2}{*}{ Region } & \multicolumn{3}{|c|}{$\begin{array}{l}\text { Assets } \\
\text { (1990) }\end{array}$} & \multicolumn{2}{|c|}{$\begin{array}{c}\text { Population } \\
\text { (1990) }\end{array}$} & \multicolumn{2}{|c|}{$\begin{array}{c}\text { Real GDP } \\
(1990)\end{array}$} & \multirow{2}{*}{$\begin{array}{c}\begin{array}{c}\text { Area } \\
\text { (sq. miles) }\end{array} \\
\text { Percent }\end{array}$} & \multirow{2}{*}{$\begin{array}{r}\begin{array}{c}\text { Votes per } \\
\text { meeting* } \\
(1968-2000)\end{array} \\
\text { Mean }\end{array}$} \\
\hline & $\begin{array}{r}\text { Billions } \\
\text { of } \\
\text { Dollars }\end{array}$ & Percent & Percent** & Millions & Percent & $\begin{array}{c}\text { Billions } \\
\text { of } 1992 \\
\text { Dollars }\end{array}$ & Percent & & \\
\hline 1. Boston & 21.5 & 6.6 & 7.9 & 12.4 & 5.0 & 334.1 & 5.6 & 1.8 & 1.00 \\
\hline 2. New York & 125.2 & 38.2 & 29.0 & 24.1 & 9.7 & 718.1 & 11.9 & 1.5 & 1.92 \\
\hline 3. Philadelphia & 9.3 & 2.8 & 7.9 & 11.5 & 4.6 & 279.6 & 4.6 & 1.0 & 1.03 \\
\hline 4. Cleveland & 19.3 & 5.9 & 9.8 & 16.1 & 6.5 & 352.0 & 5.8 & 2.1 & 0.52 \\
\hline 5. Richmond & 22.3 & 6.8 & 4.5 & 23.3 & 9.4 & 579.6 & 9.6 & 4.3 & 1.20 \\
\hline 6. Atlanta & 16.3 & 5.0 & 4.4 & 31.8 & 12.8 & 667.6 & 11.1 & 7.0 & 0.58 \\
\hline 7. Chicago & 40.9 & 12.5 & 15.2 & 30.6 & 12.3 & 694.8 & 11.5 & 5.4 & 1.28 \\
\hline 8. St. Louis & 9.2 & 2.8 & 4.2 & 12.5 & 5.0 & 253.4 & 4.2 & 5.1 & 0.62 \\
\hline 9. Minneapolis & 5.5 & 1.7 & 2.6 & 7.6 & 3.1 & 167.7 & 2.8 & 11.6 & 0.40 \\
\hline 10. Kansas City & 9.7 & 3.0 & 4.3 & 13.5 & 5.5 & 294.1 & 4.9 & 14.0 & 0.99 \\
\hline 11. Dallas & 14.5 & 4.4 & 2.8 & 18.5 & 7.4 & 436.1 & 7.2 & 10.2 & 1.02 \\
\hline 12. San Francisco & 33.7 & 10.3 & 7.4 & 46.7 & 18.8 & $1,246.7$ & 20.7 & 36.0 & 0.92 \\
\hline TOTAL & 327.6 & 100.0 & 100.0 & 248.7 & 100.0 & $6,023.8$ & 100.0 & 100.0 & 11.48 \\
\hline
\end{tabular}

*Includes meetings conducted face-to-face and by conference call. Source: Federal Reserve Bulletin, selected issues.

**Based on assets in 1920. Source: Banking and Monetary Statistics, 1914-1941 (1976). 
Table 2: Rank Ordering from Largest to Smallest by Variable

\begin{tabular}{|l|c|c|c|c|}
\hline \multicolumn{1}{|c|}{ Region } & $\begin{array}{c}\text { Votes per } \\
\text { Meeting } \\
(1968-2000)\end{array}$ & $\begin{array}{c}\text { Assets } \\
(1990)\end{array}$ & $\begin{array}{c}\text { Population } \\
(1990)\end{array}$ & $\begin{array}{c}\text { Real GDP } \\
(1990)\end{array}$ \\
\hline 1. Boston & 6 & 5 & 10 & 8 \\
2. New York & 1 & 1 & 4 & 2 \\
3. Philadelphia & 4 & 10 & 11 & 7 \\
4. Cleveland & 11 & 6 & 7 & 5 \\
5. Richmond & 3 & 4 & 5 & 4 \\
6. Atlanta & 10 & 7 & 3 & 3 \\
7. Chicago & 2 & 11 & 9 & 12 \\
8. St. Louis & 9 & 12 & 12 & 9 \\
9. Minneapolis & 12 & 9 & 8 & 6 \\
10. Kansas City & 7 & 8 & 6 & 1 \\
11. Dallas & 5 & 3 & 1 & 12 \\
12. San Francisco & 8 & & & \\
\hline
\end{tabular}


Table 3: Votes of FOMC Members, 1978-2000

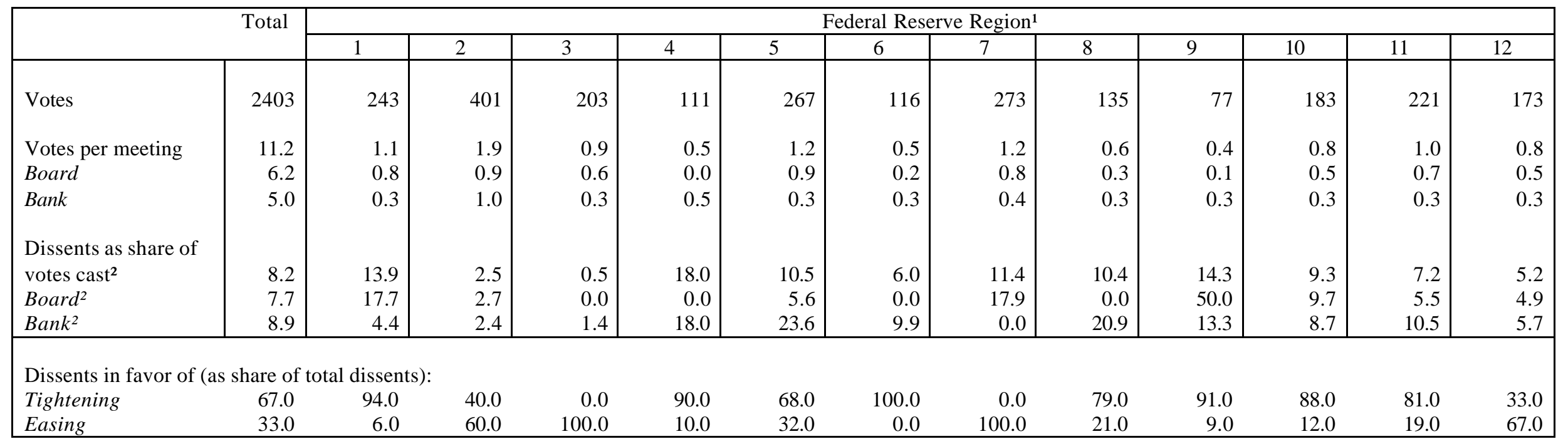

${ }^{1}$ Federal Reserve regions as follows: $1=$ Boston; $2=$ New York; 3=Philadelphia; 4=Cleveland; 5=Richmond; 6=Atlanta; $7=$ Chicago; 8=St. Louis; 9=Minneapolis; 10=Kansas City; 11=Dallas; 12=San Francisco.

${ }^{2}$ In an extended sample of 345 meetings (face-to-face and conference call) between 1968 and 2000, dissenting votes were 7 percent of all votes cast. The dissent rate of Board members was 5.8 percent, while that of Bank presidents was 8.4 percent. 
Table 4: Unemployment Difference and FOMC Votes, 1978-2000

\begin{tabular}{|c|c|c|c|c|}
\hline $\begin{array}{c}\text { Regional } \\
\text { unemployment } \\
\text { rate minus U.S. } \\
\text { unemployment } \\
\text { rate (D) }\end{array}$ & $\begin{array}{r}\text { Agree } \\
\text { with majority }\end{array}$ & $\begin{array}{r}\text { Dissent } \\
\text { easier policy }\end{array}$ & $\begin{array}{r}\text { Dissent } \\
\text { tighter policy }\end{array}$ & Total votes \\
\hline Total & 2205 & 66 & 132 & 2403 \\
\hline $\mathrm{D}>2.5$ & 14 & 1 & 0 & 15 \\
\hline $2.0<\mathrm{D}=2.5$ & 40 & 10 & 0 & 50 \\
\hline $1.5<D=2.0$ & 73 & 3 & 0 & 76 \\
\hline $1.0<\mathrm{D}=1.5$ & 158 & 6 & 12 & 176 \\
\hline $0.5<D=1.0$ & 302 & 13 & 6 & 321 \\
\hline $0.0<\mathrm{D}=0.5$ & 435 & 12 & 16 & 463 \\
\hline$-0.5<\mathrm{D}=0.0$ & 400 & 9 & 23 & 432 \\
\hline$-1.0<\mathrm{D}=-0.5$ & 369 & 6 & 20 & 395 \\
\hline$-1.5<\mathrm{D}=-1.0$ & 206 & 3 & 32 & 241 \\
\hline$-2.0<D=-1.5$ & 116 & 1 & 15 & 132 \\
\hline$-2.5<\mathrm{D}=-2.0$ & 43 & 1 & 1 & 45 \\
\hline $\mathrm{D}=-2.5$ & 49 & 1 & 7 & 57 \\
\hline Mean value of D & -0.1 & 0.5 & -0.7 & -0.1 \\
\hline t-value & 0.54 & $4.41 *$ & $5.89 *$ & \\
\hline
\end{tabular}

*Significant at the 99 percent level. T-test compares the mean value of $\mathrm{D}$ in relevant column with mean value of $\mathrm{D}$ for total votes. 
Table 5: Unemployment Difference and FOMC Votes, Board members vs. Bank presidents, 1978-2000

Board members

\begin{tabular}{|l|r|r|r|}
\hline $\begin{array}{c}\text { Regional } \\
\text { unemployment } \\
\text { rate minus U.S. } \\
\text { unemployment } \\
\text { rate (D) }\end{array}$ & $\begin{array}{r}\text { Agree } \\
\text { with majority }\end{array}$ & $\begin{array}{r}\text { Dissent } \\
\text { easier policy }\end{array}$ & $\begin{array}{r}\text { Dissent } \\
\text { tighter policy }\end{array}$ \\
\hline \\
\end{tabular}

Bank presidents

\begin{tabular}{|c|r|r|r|}
\hline $\begin{array}{c}\text { Regional } \\
\text { unemployment } \\
\text { rate minus U.S. } \\
\text { unemployment } \\
\text { rate (D) }\end{array}$ & $\begin{array}{r}\text { Agree } \\
\text { with majority }\end{array}$ & $\begin{array}{r}\text { Dissent } \\
\text { easier policy }\end{array}$ & $\begin{array}{r}\text { Dissent } \\
\text { tighter policy }\end{array}$ \\
\\
\end{tabular}

*Significant at the 99 percent level. T-test compares the mean value of D in relevant column with mean value of $\mathrm{D}$ for total votes. 
Table 6: Variable Definitions

\begin{tabular}{|c|c|c|}
\hline & $\operatorname{Lags}^{1}$ & Definition \\
\hline $\begin{array}{l}\text { Dependent variable: } \\
\text { Vli }\end{array}$ & 0 & $\begin{array}{l}\text { Equal to } 1 \text { when voter from region } i \text { dissents for tighter monetary policy. } \\
\text { Equal to } 0 \text { when voter from region } i \text { agrees with the majority. } \\
\text { Equal to }-1 \text { when voter from region } i \text { dissents for easier monetary policy. }\end{array}$ \\
\hline $\begin{array}{l}\text { Characteristic } \\
\text { dummy variables: } \\
\text { BOARD } \\
\text { MTG } \\
\text { MILLER } \\
\text { VOLCKER } \\
\text { TAPE } 2\end{array}$ & $\begin{array}{l}0 \\
0 \\
0 \\
0 \\
0\end{array}$ & $\begin{array}{l}\text { Equal to } 1 \text { if vote cast by Board member, } 0 \text { otherwise. } \\
\text { Equal to } 1 \text { if vote cast at face-to-face meeting, } 0 \text { otherwise. } \\
\text { Equal to } 1 \text { from March } 1978 \text { through July } 1979,0 \text { otherwise. } \\
\text { Equal to } 1 \text { from August } 1979 \text { through July } 1987,0 \text { otherwise. } \\
\text { Equal to } 1 \text { from November } 1993 \text { through the end of sample, } 0 \text { otherwise. }\end{array}$ \\
\hline $\begin{array}{l}\text { Regional variables: } \\
\text { UNDIFFi } \\
\text { GRVUNDi } \\
\text { TAILH } i \\
\text { TAILL } i\end{array}$ & $\begin{array}{l}1 \\
1 \\
\end{array}$ & $\begin{array}{l}\text { Unemployment rate in voter } i \text { 's region minus national unemployment rate, } \\
\text { monthly. } \\
\text { Gravity unemployment differential for voter } i \text { 's region calculated as the } \\
\text { weighted-average of the unemployment differentials (UNDIFF) in the other } \\
\text { eleven Federal Reserve regions, where the weights are inversely } \\
\text { proportional to the distance in miles between the other eleven banks and } \\
\text { bank } i \text {. } \\
\text { Equal to } 1 \text { when the value of UNDIFF } i \text { is greater than } 1.5 ; 0 \text { otherwise. } \\
\text { Equal to } 1 \text { when the value of UNDIFF } i \text { is less than }-1.5 ; 0 \text { otherwise. }\end{array}$ \\
\hline $\begin{array}{l}\text { National variables: } \\
\text { IP } \\
\text { GAP } \\
\text { UN } \\
\text { CPI } \\
\text { FEDFUND } \\
\text { Or } \\
\text { STANCE }\end{array}$ & $\begin{array}{l}1 \\
1 \\
1 \\
1\end{array}$ & $\begin{array}{l}\text { 1-month change in monthly industrial production. } \\
\text { Output gap, monthly. } \\
\text { Unemployment rate, monthly. } \\
\text { 1-month change in monthly consumer price index. } \\
\text { Fed funds rate, weekly (Wednesdays). } \\
\text { Equal to } 1 \text { when the FOMC majority tightens monetary policy. } \\
\text { Equal to } 0 \text { when the FOMC majority leaves monetary policy unchanged. } \\
\text { Equal to }-1 \text { when the FOMC majority eases monetary policy. }\end{array}$ \\
\hline
\end{tabular}

${ }^{1}$ Contemporaneous data are lag 0 . Column shows lags included in initial specification.

2Intended to capture any change in voting behavior subsequent to the decision to release transcripts of FOMC meetings to the public after a lag of five years.

${ }^{3}$ Computed as the difference between actual real GDP and potential real GDP, quarterly, where potential GDP was calculated using a Hodrick-Prescott filter; monthly data were interpolated using capacity utilization. 
Table 7: Coefficient Estimates (sample period: 1978-2000)

\begin{tabular}{|c|c|c|c|c|c|c|}
\hline \multirow{2}{*}{$\begin{array}{l}\text { Dependent } \\
\text { variable: } \\
\text { VOTE }\end{array}$} & \multicolumn{2}{|c|}{ Specification (1) } & \multicolumn{2}{|c|}{ Specification (2) } & \multicolumn{2}{|c|}{ Preferred equation } \\
\hline & Estimate & t Ratio & Estimate & t Ratio & Estimate & t Ratio \\
\hline BOARD & -0.956 & -5.9 & -0.955 & -5.9 & -0.940 & -5.8 \\
\hline MTG & 0.745 & 2.6 & 0.782 & 2.7 & 0.722 & 2.6 \\
\hline MILLER & 0.537 & 1.5 & 0.551 & 1.5 & 0.684 & 2.8 \\
\hline VOLCKER & -0.055 & -0.2 & -0.201 & -0.7 & & \\
\hline TAPE & 0.234 & 0.6 & 0.242 & 0.7 & & \\
\hline $\operatorname{UNDIFF}(-1)$ & -0.549 & -4.8 & -0.549 & -4.8 & -0.564 & -7.9 \\
\hline GRVUND (-1) & 0.454 & 1.6 & 0.414 & 1.4 & & \\
\hline TAILH $(-1)$ & -0.487 & -1.3 & -0.514 & -1.3 & & \\
\hline TAILL $(-1)$ & -0.126 & -0.4 & -0.139 & -0.4 & & \\
\hline IP $(-1)$ & 0.093 & 0.9 & 0.102 & 0.9 & & \\
\hline $\operatorname{GAP}(-1)$ & 0.013 & 0.1 & 0.017 & 0.2 & & \\
\hline $\mathrm{UN}(-1)$ & 0.105 & 0.6 & 0.105 & 0.5 & & \\
\hline CPI $(-1)$ & 0.646 & 1.8 & 0.445 & 1.5 & & \\
\hline $\begin{array}{l}\text { FEDFUND }(-1) \\
\text { STANCE }(-1)\end{array}$ & -0.039 & -1.0 & 0.015 & 0.1 & & \\
\hline THRESHOLD1 & -3.078 & -2.4 & -2.858 & -2.2 & -3.604 & -11.9 \\
\hline THRESHOLD2 & 3.981 & 3.1 & 4.197 & 3.2 & 3.383 & 11.4 \\
\hline
\end{tabular}


Table 8: Coefficient Estimates, Alternative Specifications

\begin{tabular}{|l|r|r|r|r|r|r|}
\hline \multirow{2}{*}{$\begin{array}{l}\text { Dependent } \\
\text { variable: }\end{array}$} & \multicolumn{2}{|c|}{$\begin{array}{c}\text { 1. Drop votes cast by } \\
\text { FOMC Chairman }\end{array}$} & \multicolumn{2}{c|}{$\begin{array}{c}\text { 2. Drop votes cast by } \\
\text { Bank presidents }\end{array}$} & \multicolumn{2}{c|}{$\begin{array}{c}\text { Drop votes cast by } \\
\text { Board members }\end{array}$} \\
\cline { 2 - 7 } VOTE & Estimate & t Ratio & Estimate & t Ratio & Estimate & t Ratio \\
\hline & & & & & & \\
BOARD & -0.913 & -5.7 & & & & \\
MTG & 0.727 & 2.6 & 0.509 & 1.3 & 0.908 & 2.1 \\
MILLER & 0.705 & 2.9 & 0.631 & 1.7 & 0.734 & 2.3 \\
\hline & & & & & & \\
UNDIFF (-1) & -0.552 & -7.9 & -0.874 & -8.8 & -0.218 & -2.1 \\
\hline
\end{tabular}

\begin{tabular}{|c|c|c|c|c|c|c|}
\hline \multirow{2}{*}{$\begin{array}{l}\text { Dependent } \\
\text { variable: } \\
\text { VOTE }\end{array}$} & \multicolumn{2}{|c|}{$\begin{array}{l}\text { 4. Replace UNDIFF with } \\
\text { cyclical and structural }\end{array}$} & \multicolumn{2}{|c|}{$\begin{array}{l}\text { 5. Add regional dummies } \\
\text { for Board and Bank }{ }^{1}\end{array}$} & \multicolumn{2}{|c|}{$\begin{array}{l}\text { 6. Replace UNDIFF and } \\
\text { add regional dummies }{ }^{1}\end{array}$} \\
\hline & Estimate & t Ratio & Estimate & t Ratio & Estimate & t Ratio \\
\hline BOARD & -0.944 & -5.8 & & & & \\
\hline MTG & 0.726 & 2.6 & 0.724 & 2.5 & 0.724 & 2.5 \\
\hline MILLER & 0.675 & 2.8 & 0.644 & 2.5 & 0.640 & 2.5 \\
\hline $\operatorname{UNDIFF}(-1)$ & & & -0.336 & -3.8 & & \\
\hline STRUC (-1) & -0.620 & -7.7 & & & -0.320 & -3.0 \\
\hline CYC $(-1)$ & -0.236 & -1.0 & & & -0.392 & -1.6 \\
\hline BD1 & & & 2.347 & 5.9 & 2.362 & 5.9 \\
\hline BD3 & & & 0.257 & 0.5 & 0.251 & 0.4 \\
\hline BD5 & & & -1.058 & -2.3 & -1.043 & -2.2 \\
\hline BD6 & & & 0.116 & 0.1 & 0.114 & 0.1 \\
\hline BD7 & & & -2.236 & -6.0 & -2.243 & -6.0 \\
\hline BD8 & & & 0.074 & 0.1 & 0.079 & 0.1 \\
\hline BD10 & & & 1.443 & 3.0 & 1.459 & 3.0 \\
\hline BD11 & & & 1.208 & 2.5 & 1.221 & 2.5 \\
\hline BD12 & & & -1.106 & -2.1 & -1.111 & -2.1 \\
\hline BK1 & & & -0.237 & -0.3 & -0.227 & -0.3 \\
\hline BK3 & & & -0.297 & -0.4 & -0.299 & -0.4 \\
\hline BK4 & & & 2.574 & 6.0 & 2.566 & 6.0 \\
\hline BK5 & & & 2.842 & 6.6 & 2.859 & 6.5 \\
\hline BK6 & & & 2.107 & 4.1 & 2.108 & 4.1 \\
\hline BK7 & & & 0.241 & 0.4 & 0.233 & 0.4 \\
\hline BK8 & & & 2.536 & 5.1 & 2.534 & 5.1 \\
\hline BK9 & & & 1.862 & 3.8 & 1.888 & 3.8 \\
\hline BK10 & & & 1.257 & 2.1 & 1.279 & 2.1 \\
\hline BK11 & & & 1.229 & 2.1 & 1.243 & 2.2 \\
\hline BK12 & & & 1.069 & 1.6 & 1.062 & 1.6 \\
\hline
\end{tabular}

${ }^{1}$ BD4 and BD9 dropped owing to absence of observations.

Federal Reserve regions as follows: 1=Boston; 2=New York; 3=Philadelphia; 4=Cleveland; 5=Richmond; 6=Atlanta; 7=Chicago; 8=St. Louis; 9=Minneapolis; 10=Kansas City; 11=Dallas; 12=San Francisco. 
Table 9: Marginal Effects ${ }^{1}$ (percentage points)

\begin{tabular}{|l|r|r|r|r|r|r|}
\hline \multirow{2}{*}{$\begin{array}{l}\text { Dependent } \\
\text { variable: }\end{array}$} & \multicolumn{3}{|c|}{ Preferred equation } & \multicolumn{3}{c|}{ 1. Drop votes cast by FOMC Chairman } \\
\cline { 2 - 7 } VOTE & $\operatorname{Pr}[\mathrm{VL}=-1]$ & $\operatorname{Pr}[\mathrm{VL}=0]$ & $\operatorname{Pr}[\mathrm{VL}=1]$ & $\operatorname{Pr}[\mathrm{VL}=-1]$ & $\operatorname{Pr}[\mathrm{VL}=0]$ & $\operatorname{Pr}[\mathrm{VL}=1]$ \\
\hline & & & & & & \\
BOARD & 1.8 & 2.4 & -4.2 & 2.0 & 2.3 & -4.3 \\
MTG & -1.9 & -0.4 & 2.3 & -2.1 & -0.5 & 2.6 \\
MILLER & -1.1 & -2.6 & 3.7 & -1.2 & -3.0 & 4.2 \\
\hline & & & & & & \\
UNDIFF $(-1)$ & 1.1 & 1.2 & -2.3 & 1.2 & 1.3 & -2.5 \\
\hline
\end{tabular}

\begin{tabular}{|c|c|c|c|c|c|c|}
\hline $\begin{array}{l}\text { Dependent } \\
\text { variable: }\end{array}$ & \multicolumn{3}{|c|}{ 2. Drop votes cast by Bank presidents } & \multicolumn{3}{|c|}{ 3. Drop votes cast by Board members } \\
\hline VOTE & $\operatorname{Pr}[\mathrm{VL}=-1]$ & $\operatorname{Pr}[\mathrm{VL}=0]$ & $\operatorname{Pr}[\mathrm{VL}=1]$ & $\operatorname{Pr}[\mathrm{VL}=-1]$ & $\operatorname{Pr}[\mathrm{VL}=0]$ & $\operatorname{Pr}[\mathrm{VL}=1]$ \\
\hline $\begin{array}{l}\text { BOARD } \\
\text { MTG } \\
\text { MILLER }\end{array}$ & $\begin{array}{l}-1.6 \\
-1.3\end{array}$ & $\begin{array}{r}0.5 \\
-0.7\end{array}$ & $\begin{array}{l}1.1 \\
2.0\end{array}$ & $\begin{array}{l}-1.4 \\
-0.6\end{array}$ & $\begin{array}{l}-3.2 \\
-5.8\end{array}$ & $\begin{array}{l}4.6 \\
6.4\end{array}$ \\
\hline $\operatorname{UNDIFF}(-1)$ & 2.2 & 0.0 & -2.2 & 0.2 & 1.3 & -1.5 \\
\hline
\end{tabular}

\begin{tabular}{|c|c|c|c|}
\hline \multirow{2}{*}{$\begin{array}{l}\text { Dependent } \\
\text { variable: } \\
\text { VOTE }\end{array}$} & \multicolumn{3}{|c|}{$\begin{array}{l}\text { 4. Replace UNDIFF with cyclical and } \\
\text { structural }\end{array}$} \\
\hline & $\operatorname{Pr}[\mathrm{VL}=-1]$ & $\operatorname{Pr}[\mathrm{VL}=0]$ & $\operatorname{Pr}[\mathrm{VL}=1]$ \\
\hline BOARD & 1.8 & 2.4 & -4.2 \\
\hline MTG & -1.9 & -0.4 & 2.3 \\
\hline MILLER & -1.0 & -2.5 & 3.5 \\
\hline STRUC $(-1)$ & 1.2 & 1.3 & -2.5 \\
\hline CYC $(-1)$ & 0.5 & 0.5 & -1.0 \\
\hline
\end{tabular}

${ }^{1}$ By definition, the marginal effects sum to zero across categories. 
Table 9: (continued) Marginal Effects ${ }^{1}$ (percentage points)

\begin{tabular}{|c|c|c|c|c|c|c|}
\hline \multirow{2}{*}{$\begin{array}{l}\text { Dependent } \\
\text { variable: } \\
\text { VOTE }\end{array}$} & \multicolumn{3}{|c|}{$\begin{array}{l}\text { 5. Add regional dummies for Board and } \\
\text { Bank }\end{array}$} & \multicolumn{3}{|c|}{$\begin{array}{l}\text { 6. Replace UNDIFF and add regional } \\
\text { dummies }\end{array}$} \\
\hline & $\operatorname{Pr}[\mathrm{VL}=-1]$ & $\operatorname{Pr}[\mathrm{VL}=0]$ & $\operatorname{Pr}[\mathrm{VL}=1]$ & $\operatorname{Pr}[\mathrm{VL}=-1]$ & $\operatorname{Pr}[\mathrm{VL}=0]$ & $\operatorname{Pr}[\mathrm{VL}=1]$ \\
\hline $\begin{array}{l}\text { BOARD } \\
\text { MTG } \\
\text { MILLER }\end{array}$ & $\begin{array}{l}-0.9 \\
-0.5 \\
\end{array}$ & $\begin{array}{l}-0.4 \\
-1.5 \\
\end{array}$ & $\begin{array}{l}1.3 \\
2.0 \\
\end{array}$ & $\begin{array}{l}-0.9 \\
-0.5 \\
\end{array}$ & $\begin{array}{l}-0.4 \\
-1.5 \\
\end{array}$ & $\begin{array}{l}1.3 \\
2.0 \\
\end{array}$ \\
\hline $\begin{array}{l}\text { BD1* } \\
\text { BD3 } \\
\text { BD5* } \\
\text { BD6 } \\
\text { BD7* } \\
\text { BD8 } \\
\text { BD10* } \\
\text { BD11* } \\
\text { BD12* }\end{array}$ & $\begin{array}{r}-1.0 \\
-0.2 \\
1.6 \\
-0.1 \\
6.3 \\
-0.1 \\
-0.8 \\
-0.7 \\
1.8 \\
\end{array}$ & $\begin{array}{r}-15.0 \\
-0.5 \\
0.1 \\
-0.2 \\
-3.8 \\
-0.1 \\
-6.0 \\
-4.3 \\
-0.1 \\
\end{array}$ & $\begin{array}{r}16.0 \\
0.7 \\
-1.7 \\
0.3 \\
-2.5 \\
0.2 \\
6.8 \\
5.0 \\
-1.7 \\
\end{array}$ & $\begin{array}{r}-1.0 \\
-0.2 \\
1.6 \\
-0.1 \\
6.4 \\
-0.1 \\
-0.8 \\
-0.7 \\
1.8 \\
\end{array}$ & $\begin{array}{r}-15.3 \\
-0.5 \\
0.1 \\
-0.2 \\
-3.8 \\
-0.1 \\
-6.1 \\
-4.3 \\
-0.1 \\
\end{array}$ & $\begin{array}{r}16.3 \\
0.7 \\
-1.7 \\
0.3 \\
-2.6 \\
0.2 \\
6.9 \\
5.0 \\
-1.7 \\
\end{array}$ \\
\hline $\begin{array}{l}\text { BK1 } \\
\text { BK3 } \\
\text { BK4* } \\
\text { BK5* } \\
\text { BK6* } \\
\text { BK7 } \\
\text { BK8* } \\
\text { BK9* } \\
\text { BK10* } \\
\text { BK11* } \\
\text { BK12 }\end{array}$ & $\begin{array}{r}0.3 \\
0.3 \\
-1.0 \\
1.6 \\
-0.9 \\
-0.2 \\
-0.9 \\
-0.9 \\
-0.7 \\
-0.7 \\
-0.6\end{array}$ & $\begin{array}{r}0.3 \\
0.3 \\
-19.4 \\
0.1 \\
-13.1 \\
-0.4 \\
-19.6 \\
-10.1 \\
-4.8 \\
-4.6 \\
-3.6\end{array}$ & $\begin{array}{r}-0.6 \\
-0.6 \\
20.4 \\
-1.7 \\
14.0 \\
0.6 \\
20.5 \\
11.0 \\
5.5 \\
5.3 \\
4.2\end{array}$ & $\begin{array}{r}0.2 \\
0.3 \\
-1.0 \\
1.6 \\
-0.9 \\
-0.2 \\
-0.9 \\
-0.9 \\
-0.7 \\
-0.7 \\
-0.6\end{array}$ & $\begin{array}{r}0.3 \\
0.3 \\
-19.3 \\
0.1 \\
-13.1 \\
-0.4 \\
-19.6 \\
-10.3 \\
-4.9 \\
-4.7 \\
-3.6\end{array}$ & $\begin{array}{r}-0.5 \\
-0.6 \\
20.3 \\
-1.7 \\
14.0 \\
0.6 \\
20.5 \\
11.2 \\
5.6 \\
5.4 \\
4.2\end{array}$ \\
\hline $\begin{array}{l}\text { UNDIFF }(-1) \\
\text { STRUC }(-1) \\
\text { CYC }(-1)\end{array}$ & 0.3 & 0.5 & -0.8 & $\begin{array}{l}0.3 \\
0.4\end{array}$ & $\begin{array}{l}0.4 \\
0.6\end{array}$ & $\begin{array}{l}-0.7 \\
-1.0 \\
\end{array}$ \\
\hline
\end{tabular}

${ }^{1}$ BD4 and BD9 dropped owing to absence of observations.

*Underlying coefficient estimate significant at the 97.5 percent level.

Federal Reserve regions as follows: 1=Boston; 2=New York; 3=Philadelphia; 4=Cleveland; 5=Richmond; 6=Atlanta; 7=Chicago; 8=St. Louis; 9=Minneapolis; 10=Kansas City; 11=Dallas; 12=San Francisco. 
Table 10: ECB Voting Under Hypothetical Rule

\section{Number of Governing Council votes \\ In support of monetary tightening or against monetary easing}

\begin{tabular}{|l|c|c|c|c|c|c|c|}
\hline \multicolumn{1}{|c|}{ National minus euro-area inflation in month (-1) for different threshold values } \\
\hline & \multicolumn{6}{|c|}{ Threshold value greater than or equal to } & $\begin{array}{c}\text { Actual change in ST rate } \\
\text { (basis points) }\end{array}$ \\
\cline { 2 - 8 } & 0.25 & 0.50 & 0.75 & 1.00 & 1.25 & 1.50 & \\
\hline March 1999 & 9 & 6 & 6 & 6 & 1 & 1 & -50 \\
April 2001 & 7 & 7 & 7 & 6 & 4 & 3 & -25 \\
July 2001 & 7 & 7 & 7 & 5 & 4 & 2 & -25 \\
August 2001 & 7 & 7 & 7 & 7 & 4 & 2 & -50 \\
\hline
\end{tabular}

Number of Governing Council votes

In support of monetary easing or against monetary tightening

\begin{tabular}{|c|c|c|c|c|c|c|c|}
\hline \multicolumn{8}{|c|}{ National minus euro-area inflation in month (-1) for different threshold values } \\
\hline & \multicolumn{6}{|c|}{ Threshold value less than or equal to } & \multirow{2}{*}{$\begin{array}{l}\text { Actual change in ST rate } \\
\text { (basis points) }\end{array}$} \\
\hline & -0.25 & -0.50 & -0.75 & -1.00 & -1.25 & -1.50 & \\
\hline October 1999 & 5 & 3 & 0 & 0 & 0 & 0 & 50 \\
\hline January 2000 & 6 & 2 & 1 & 1 & 1 & 1 & 25 \\
\hline February 2000 & 5 & 4 & 0 & 0 & 0 & 0 & 25 \\
\hline March 2000 & 5 & 3 & 0 & 0 & 0 & 0 & 25 \\
\hline May 2000 & 5 & 0 & 0 & 0 & 0 & 0 & 50 \\
\hline August 2000 & 5 & 0 & 0 & 0 & 0 & 0 & 25 \\
\hline September 2000 & 3 & 0 & 0 & 0 & 0 & 0 & 25 \\
\hline
\end{tabular}


Table 11: ECB Voting Under Hypothetical Rule

Number of Executive Board votes

In support of monetary tightening or against monetary easing

\begin{tabular}{|l|c|c|c|c|c|c|c|}
\hline \multicolumn{10}{|c|}{ National minus euro-area inflation in month (-1) for different threshold values } \\
\hline & \multicolumn{6}{|c|}{ Threshold value greater than or equal to } & $\begin{array}{c}\text { Actual change in ST rate } \\
\text { (basis points) }\end{array}$ \\
\cline { 2 - 8 } & 0.25 & 0.50 & 0.75 & 1.00 & 1.25 & 1.50 & \\
\hline March 1999 & 3 & 2 & 2 & 2 & 0 & 0 & -50 \\
April 2001 & 2 & 2 & 2 & 2 & 1 & 1 & -25 \\
July 2001 & 2 & 2 & 2 & 1 & 1 & 1 & -25 \\
August 2001 & 2 & 2 & 2 & 2 & 1 & 1 & -50 \\
\hline
\end{tabular}

Number of Executive Board votes

In support of monetary easing or against monetary tightening

\begin{tabular}{|c|c|c|c|c|c|c|c|}
\hline \multicolumn{8}{|c|}{ National minus euro-area inflation in month (-1) for different threshold values } \\
\hline & \multicolumn{6}{|c|}{ Threshold value less than or equal to } & \multirow{2}{*}{$\begin{array}{l}\text { Actual change in ST rate } \\
\text { (basis points) }\end{array}$} \\
\hline & -0.25 & -0.50 & -0.75 & -1.00 & -1.25 & -1.50 & \\
\hline October 1999 & 2 & 1 & 0 & 0 & 0 & 0 & 50 \\
\hline January 2000 & 2 & 0 & 0 & 0 & 0 & 0 & 25 \\
\hline February 2000 & 2 & 2 & 0 & 0 & 0 & 0 & 25 \\
\hline March 2000 & 2 & 1 & 0 & 0 & 0 & 0 & 25 \\
\hline May 2000 & 2 & 0 & 0 & 0 & 0 & 0 & 50 \\
\hline August 2000 & 2 & 0 & 0 & 0 & 0 & 0 & 25 \\
\hline September 2000 & 1 & 0 & 0 & 0 & 0 & 0 & 25 \\
\hline
\end{tabular}




\section{References}

Abrams, R. K., Froyen, R. and Waud, R. N. (1980), 'Monetary Policy Reaction Functions, Consistent Expectations, and The Burns Era', Journal of Money, Credit, and Banking, vol. 12, February, pp. 30-42.

Alesina, A. (1987), 'Macroeconomic Policy in a Two-Party System as a Repeated Game', Quarterly Journal of Economics, vol. 102, August, pp. 651-678.

Alesina, A. and Grilli, V. (1992), 'The European Central Bank: Reshaping Monetary Politics in Europe', in M. Canzoneri, V. Grilli and P. Masson (eds.), Establishing a Central Bank. Issues in Europe and Lessons from the US, Cambridge University Press.

Alesina, A. and Sachs, J. (1988), 'Political Parties and the Business Cycle in the United States, 1948-1984', Journal of Money, Credit, and Banking, vol. 20, February, pp. 6381.

Annual Report, Selected years, Board of Governors of the Federal Reserve System, Washington, D.C.

Banking and Monetary Statistics, 1914-1941. (1976), Board of Governors of the Federal Reserve System, Washington, D.C.

Baldwin, R. E., Berglöf, E., Giavazzi, F. and Widgrén, M. (2001), Nice Try: Should the Treaty of Nice be Ratified?, Centre for Economic Policy Research: London.

Belden, S. (1989), 'Policy Preferences of FOMC Members as Revealed by Dissenting Votes', Journal of Money, Credit, and Banking, vol. 21, November, pp. 432-441.

Blinder, A., Goodhart, C., Hildebrand, P., Lipton, D. and Wyplosz, C. (2001), 'How Do Central Banks Talk?', Geneva Reports on the World Economy, Number 3, Centre for Economic Policy Research: London.

Federal Open Market Committee Transcripts, Selected years, Board of Governors of the Federal Reserve System, Washington, D.C. http://www.federalreserve.gov/fomc/transcripts

Gildea, J. A. (1990), 'Explaining FOMC Members' Votes', in T. Mayer (ed.), The Political Economy of American Monetary Policy, Cambridge University Press.

Gildea, J. A. (1992), 'The Regional Representation of Federal Reserve Bank Presidents', Journal of Money, Credit, and Banking, vol. 24, May, pp. 215-225.

Greene, W. H. (2000), Econometric Analysis, Prentice Hall International.

Greenspan, A. (2000), 'Productivity and Efficiency in the Federal Reserve System', Speech given at the dedication of the new Birmingham Branch Building of the Federal Reserve Bank of Atlanta, December. 
Havrilesky, T. M. and Gildea., J. (1991), 'The Polic y Preferences of FOMC Members as Revealed by Dissenting Votes', Journal of Money, Credit, and Banking, vol. 23, February, pp. 130-138.

, (1995), 'The Biases of Federal Reserve Bank Presidents', Economic Inquiry, vol. XXXIII, April, pp. 274-284.

(1992), 'Reliable and Unreliable Partisan Appointees to the Board of Governors', Public Choice, vol. 73, May, pp. 397-417.

Havrilesky, T. M. and Schweitzer, R. (1990), 'A Theory of FOMC Dissent Voting with Evidence from the Time Series', in T. Mayer (ed.), The Political Economy of American Monetary Policy, Cambridge University Press.

Hearings Before the Committee on Banking, Housing, and Urban Affairs of the United States Senate. (1991), 'Nominations of Raoul Lord Carroll and Lawrence B. Lindsey', April 22 and May 7.

Hibbs, D. (1977), The American Political Economy: Electoral Policy and Macroeconomics in Contemporary America, Harvard University Press.

Johnson, R. T. (1995), Historical Beginnings. The Federal Reserve, Federal Reserve Bank of Boston.

Meade, E. E. and Sheets, D. N. (1999), 'Centralization vs. Decentralization in the Federal Reserve System: Lessons for the European Central Bank', in E. E. Meade (ed.), The European Central Bank: How accountable? How Decentralized?, American Institute for Contemporary German Studies, Conference Report 4, February, pp. 5367.

'Minutes of the Federal Open Market Committee', Selected years, Federal Reserve Bulletin, Board of Governors of the Federal Reserve System, Washington, D.C.

Purposes and Functions. (1994), Board of Governors of the Federal Reserve System. Washington, D.C.

Tootell, G. M. B. (1991), 'Regional Economic Conditions and the FOMC Votes of District Presidents', New England Economic Review, Federal Reserve Bank of Boston, March/April, pp. 3-16.

(1991), 'Are District Presidents More Conservative than Board Governors?', New England Economic Review, Federal Reserve Bank of Boston, September/October, pp. 3-12.

Woodward, B. (2000), Maestro: Greenspan's Fed and the American Boom, Simon and Schuster. 


\section{CENTRE FOR ECONOMIC PERFORMANCE \\ Recent Discussion Papers}

522 D. Quah

521 D. Quah

520 C. A. Pissarides

519 D. T. Mortensen

C. A. Pissarides

518 D. Clark

R. Fahr

517 J. Blanden
A. Goodman
P. Gregg
S. Machin

516 A. Chevalier

T. K. Viitanen

515 A. Bryson

R. Gomez

M. Gunderson

N. Meltz

514 A. Manning

513 H. Steedman

512 R. Gomez

M. Gunderson

N. Meltz

511 G. Duranton

D. Puga

510 P.-P. Combes

G. Duranton

509 R. Griffith

S. Redding

J. Van Reenen
Technology Dissemination and Economic Growth: Some Lessons for the New Economy

Spatial Agglomeration Dynamics

Company Start-Up Costs and Emp loyment

Taxes, Subsidies and Equilibrium Labor Market Outcomes

The Promise of Workplace Training for Non-College

Bound Youth: Theory and Evidence from Germany

Change in Intergenerational Mobility in Britain

The Long-Run Labour Market Consequences of Teenage

Motherhood in Britain

Youth Adult Differences in the Demand for Unionisation:

Are American, British and Canadian Workers That

Different?

Monopsony and the Efficiency of Labor Market Interventions

Benchmarking Apprenticeship: UK and Continental Europe Compared

From 'Playstations' to 'Workstations': Youth Preferences for Unionisation

From Sectoral to Functional Urban Specialisation

Labor Pooling, Labour Poaching, and Spatial Clustering

Measuring the Cost Effectiveness of an R\&D Tax Credit

for the UK 
508 H. G. Overman

S. Redding

A. J. Venables

507 A. J. Venables

506 R. Dickens

D. T. Ellwood

505 M. Ghell

504 A. Charlwood

503 D. Marsden

S. French

K. Kubo

502 S. Nickell

L. Nunziata

W. Ochel

G. Quintini

$501 \quad$ S. Redding M. Vera-Martin

$500 \quad$ Edited by

D. Marsden and

H. Stephenson

499 A. Manning

498 A. Charlwood

497

M. Keil

D. Robertson

J. Symons
The Economic Geography of Trade, Production and Income: A Survey of Empirics

Geography and International Inequalities: the Impact of New Technologies

Whither Poverty in Great Britain and the United States?

The Determinants of Changing Poverty and Whether Work Will Work

Fixed-Term Contracts and the Duration Distribution of Unemployment

Influences on Trade Union Organising Effectiveness in Great Britain

Does Performance Pay De-Motivate, and Does It Matter?

The Beveridge Curve, Unemployment and Wages in the OECD from the 1960s to the 1990s

Factor Endowments and Production in European Regions

Labour Law and Social Ins urance in the New Economy: A Debate on the Supiot Report

A Generalised Model of Monopsony

Why Do Non-Union Employees Want to Unionise?

Evidence from Britain

Minimum Wages and Employment

To order a discussion paper, please contact the Publications Unit Tel 02079557673 Fax 02079557595 Email info@cep.lse.ac.uk Web site http://cep.lse.ac.uk 